\title{
A REVIEW AND SYSTEMIZATION OF THE TRADITIONAL MONGOLIAN YURT (GER)
}

\author{
${ }^{1}$ Gantumur TSOVOODAVAA, ${ }^{2}$ Rowell Ray Lim SHIH \\ ${ }^{3}$ Mohammad Reza Ganjali BONJAR, ${ }^{4}$ István KISTELEGDI \\ ${ }^{1,2,3}$ Breuer Marcel Doctoral School, Institute of Architecture, Faculty of Engineering and \\ Information Technology, University of Pécs, Boszorkány u. 2, H-7624 Pécs, Hungary \\ e-mail: ${ }^{1}$ tsovoog@gmail.com, ${ }^{2}$ rowellshih@yahoo.com, ${ }^{3}$ mohammadrezaa.ganjali@gmail.com \\ and \\ ${ }^{1}$ School of Civil Engineering and Architecture, Mongolian University of Science and \\ Technology, Ulaanbaatar, Mongolia \\ ${ }^{2}$ Department of Architecture. School of Architecture, Fine Arts and Design, University of San \\ Carlos Technological Center, Cebu City, Cebu, Philippines \\ ${ }^{4}$ Faculty of Engineering and Information Technology, University of Pécs, Boszorkány u. 2 \\ H-7624 Pécs, Hungary ${ }^{4}$ kistelegdisoma@mik.pte.hu
}

Received 24 January 2018; accepted 28 May 2018

\begin{abstract}
Over the course of human history, vernacular architecture has developed according to the climate, culture, geographical conditions and lifestyle. One of the fascinating designs from around the world that have survived over the years is the yurt. Although it has developed over thousands of years, the basic round form of the yurt remains unchanged. Nomadic people have traditionally utilized the yurt because due to its portability, lightness and can be erected easily. This unique architectural structure allowed the nomadic tribes to live and thrive in the harsh Central Asian climate. In this study, the history, design, and construction of the traditional yurt are reviewed and also proofed whether literature about the building physics performance of the yurt still exists.
\end{abstract}

Keywords: Vernacular architecture, Nomadic architecture, Yurt (Ger) structure, Natural ventilation

\section{Introduction}

The yurt is one of the oldest man-made structures in the world. Yurts have been the home for the Mongolians for over 2500 years. The yurt shelter is a basic vernacular architectural style for nomadic cultural countries around the world [1], [2], [3], [4]. The basic round form of the yurt changed little over thousands of years and due to the lightweight and collapsible wooden frame, it can be erected in a few minutes. The yurt is spacious inside and due to the unique design, people can comfortably live inside the yurt in any climate. This is because of the passive ventilation system called the 'dome chilling effect [5], [6] that the yurt is specially designed for. The size of the yurt usually 
follows the size of the crown, which usually four times bigger than the crown radius [1], [3]. The Mongolian yurt has a more precise module due to the dimension of the crown holes of the poles [1]. This shelter is constructed of several lattices forming a circular wall, which meets a post and lintel doorway. All materials used in the yurt are organic, which is made up of wood and skin of life stock animals. The traditional materials used in the construction of the Mongolian yurt are the sheep wool, skin of the cow, yak, camel, horse hair and tail. The collapsible wall is made of wood sticks and is fused by camel skin, which is easily applied and is very strong and durable [7], [8], [9], [1]. When fully packed, the yurt is easily transported by camel, yak or by a small car.

\section{Review on the historical evolution of the yurt}

Yurts have been in use for more than five thousand years in the Mongolian steppe [1]. A recent archaeological expedition found yurts on rock paintings in the Bugat soum, Uvurkhangai province, and Tsagaan Salaa, Bayan-Ulgii province of Mongolia [1]. When humans began domesticating life stock animals they were already using yurtlike houses. In the first nomadic empire Hunnu (Xiongnu- BC $4^{\text {th }}-1^{\text {st }}$ century) located in the Mongolian area, the people were already living in yurts. The Chinese historical book called 'Shi Ji' wrote by Sy Machani stated that the people during this time ate meat and wear the skin of life stock animals and covering the yurt in animal's wool and skin [10], [11], [1], [8]. Around the $1^{\text {st }}$ century, the Mongolian area experienced a severe winter and a devastating summer drought. The nomads lost hundreds of animals, which resulted in a mass migration of several tribes to the South, the Indian region and parts of Europe. Although a small number of tribes remained in the Mongolian region, it was the start of the Mongolian yurts spreading around the world. After the fall of the Hunnu Empire, nomadic states of Xianbei, Tureg, and Uigar used the yurt for basic shelter [12], [1] [10]. It was in the $13^{\text {th }}$ century that the Mongolian yurt had developed different types and varieties, each adapted to the unique local culture and location. It was also during this time that Chinggis Khan established the biggest Mongolian Empire. The armies of Chinggis Khan used different sizes of yurts. The yurts for the king and queen have carts that were powered by 33 oxen. Moreover, the generals and foot soldiers have yurts with carts powered by around 3 to 11 oxen. Some yurts were not collapsible and had a very strong inner structure that served as protection for the village during the night.

In the $13-17^{\text {th }}$ century, Abtaisain khan's (1554-1588) yurt was recorded to have used 8 to 15 huge wall yurts [1]. The yurt was built to house 300 people, which have stone and brick floorings with smoke pipes for heating [10]. Presently, original stone floors (45 $\mathrm{m}$ radius) still exist in the Erdene Zuu, Kharkhorin, Uvurkhangai province of Mongolia. The original felt door was changed to a wooden door and the light crown (Saraalj crown) (Fig. 1) was changed to a compounded crown because the people did not move far and stay in the cities [1], [4], [7].

\section{Structure and materials}

The basic yurt structure has two main parts, which are the collapsible wooden frame and sheep wool felt covering. 
Types of the crown
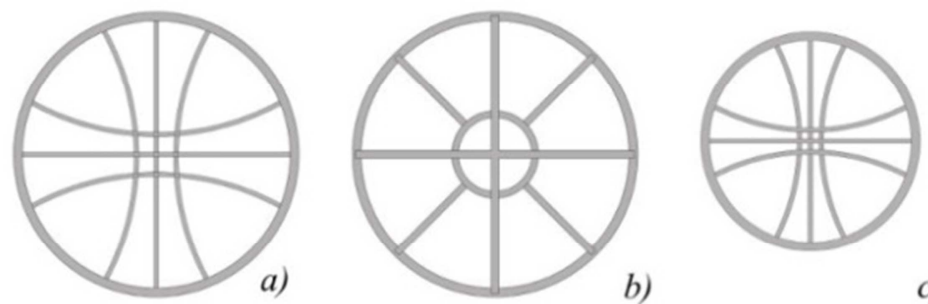

b)

c)
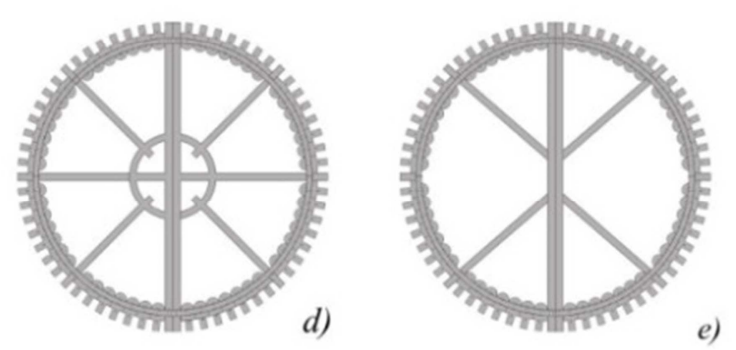

Fig. 1. a) Saraalj crown, b) Khorol crown, c) High and small Sarkhinag crown, d) Khorol crown with trussed wood, e) Separable crown (Sarkhinag)

\subsection{Collapsible wooden frame}

Crown: The yurt has only one window located at the top and the form follows the round crown. The main function of the crown is to support the entire structure, light admittance, and ventilation. The crown is connected to the poles and supports the felt roof. Ancient Mongolians and some countries used pressed wood made by birch wood, brushwood or larch wood. In humid areas, larch wood is more suitable but can be very heavy [13], [7]. Presently, Mongolian, Inner Mongolian, and American yurts have harder crowns than old ones, which are glued and compounded crown. The crown has many types (Fig. 1) [1], [7].

Poles (Uni): The poles are usually made of wooden sticks and connect the crown and walls of the yurt [4].

Walls: The size and shape of the yurt depend on the number of the walls, wall parts, respectively. The wall transmits the compression weight on the soil, while the wooden lattice makes the walls collapsible. The binding is made of cattle hide, which strengthens the exterior of the yurt. The yurt can be large or small, depending on the number of walls $(4,5,6,8,10$ and 12) and connects to a door.

Door: During ancient times the people used doors made of felt shutters, lifting it up to open or close. This simple method operated as a door and in present times the nomads replaced these with wooden doors. The door is considered the heaviest among 
the parts of the yurt and in term construction the door is made with single or double boards.

Column: Columns are the main vertical supporters of the yurt. The yurts with 4, 5, 6 wall parts have two columns and those with $8,10,12$ wall parts have four columns. Columns support the crown from the bottom and safely secure all components of the yurt.

\subsection{Felt covering}

The roof, walls, and urkh (cover for the hole on the top) are made of felting. The covering materials are handmade which is composed of wool and the hair of life stock animals. In early times, they used the white color of the bone or limestone for painting the felt. For waterproofing, they used goat fat and in present times standard waterproofing materials are used for protecting the felt. Finally, felt covers are attached by lines as three belts on the wall parts.

\section{Types of yurts}

There are different varieties of yurt found around the world. Today's yurts vary according to use: commercial, tourism and residential. Fig. 2 demonstrates 31 countries using yurts and out of which 13 countries apply the traditional yurt. The basic form of the yurt evolved over the years, while the location and climate had a huge impact on its design and shape [14]. The locally originated (Mongolian) yurt was developed by the traditional means. Foreign yurts adapted the original Mongolian yurt in some countries, whereby from region to region alternatives of different designs appear. Presently, most countries use the yurts for business and tourism purposes (Fig. 2.) [1], [2].

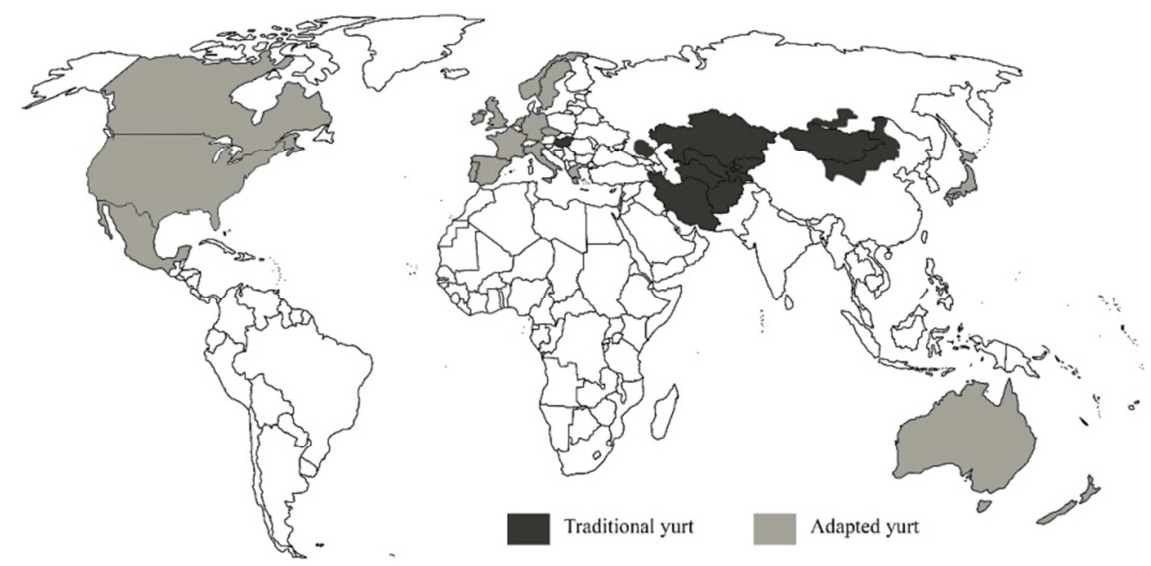

Fig. 2. The location map of traditional and adapted yurt in use today 
Mongolian Yurt: The Mongolian modern yurt was used from 1900 by the Kalmyk (people are one nation of Mongolia, live in Russia) and Buryatia (people are one nation of Mongolia, live in the south side of Russia) tribes, which were part of Russia. During this time, they added details of Buddhist symbols on the yurt. They also changed the crown to 'Khorol' crown (Fig. 1) and added some pattern details on the wood. It was also this time, while the yurt was treated more of the artistic expression of the user. The yurt was becoming more and more beautiful, in terms of artistic qualities. The Mongolian yurt (Fig. 3) is considered to be the most developed ger because it is the largest, most solid as well as most decorated one that was used first in the steppe of Mongolia [15], [1], [7].

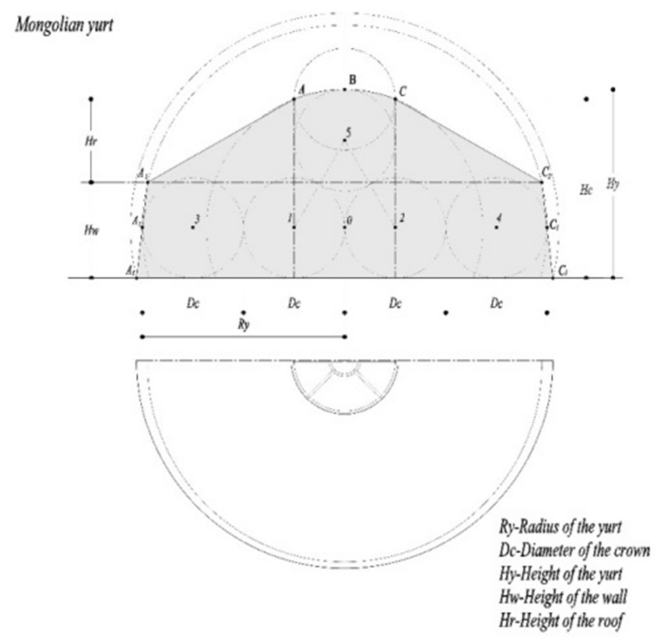

Fig. 3. The Classic form of a Mongolian Yurt

Hunnu Yurt: The Hunnu yurt was the first full dome-shaped yurt. The poles are curved like an arc and the crown was composed of two connected arches of the same size (Fig. 4). Currently, many countries have adopted this type of crown (Fig. 1), which is called the 'Saraalj' crown [1], [7].

Mongolian Empire Yurt: The main difference of this yurt is the recognizable double crown, which acts like a chimney that draws smoke out of the yurt (Fig. 4). This design also helps to stabilize the oxen carts. It was also during this period that the Mongolian nomads used it with oxen cart, which resulted in different varieties and functions of the yurt [1], [7].

Inner Mongolian Yurt: As it is shown in Fig. 5, the Inner Mongolian yurt has significantly bigger crown than the Mongolian yurt. In Inner Mongolia the yurt is still very popular, and Inner Mongolians keep the traditional and cultural way. This type of yurt consists of wooden trusses, instead of pole holes (Fig. 1) and the trusses are connected directly to the poles. Finally, the poles are lightly cantilevered from the sides of the wall [7], [9], [15]. 
Hungarian Yurt: The only country that possesses the traditional yurt in Europe, is Hungary. During ancient times, Hungarian people lived in typical roundhouse yurts. (Fig. 5) [16], this type of Hungarian yurt is closely related to the Hunnu yurt.

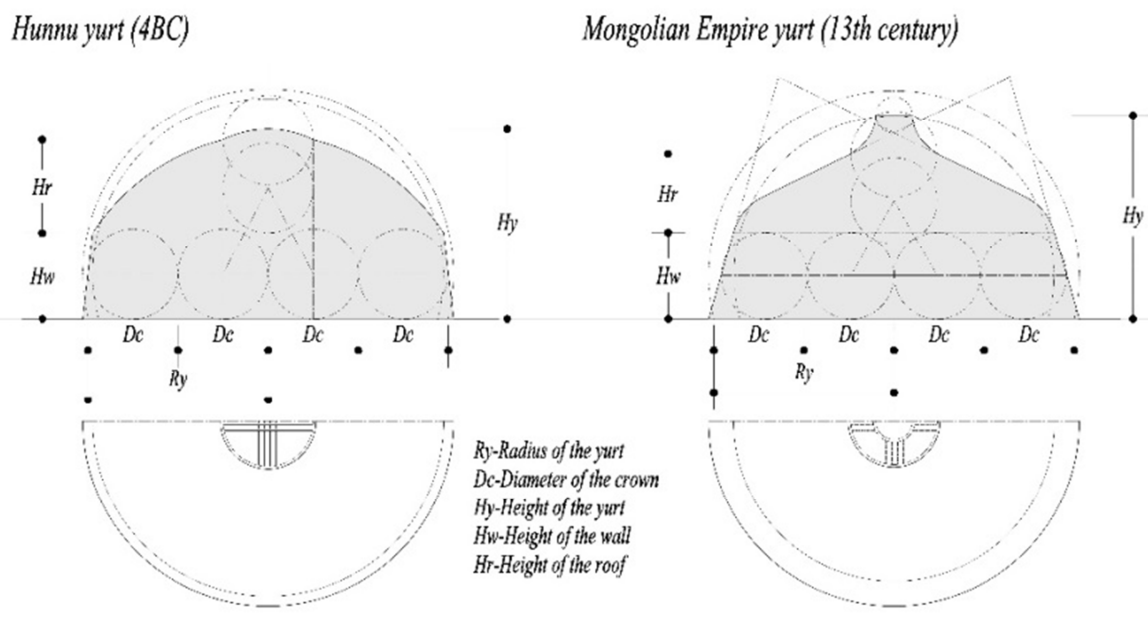

Fig. 4. Drawing of Hunnu and Mongolian Empire yurt
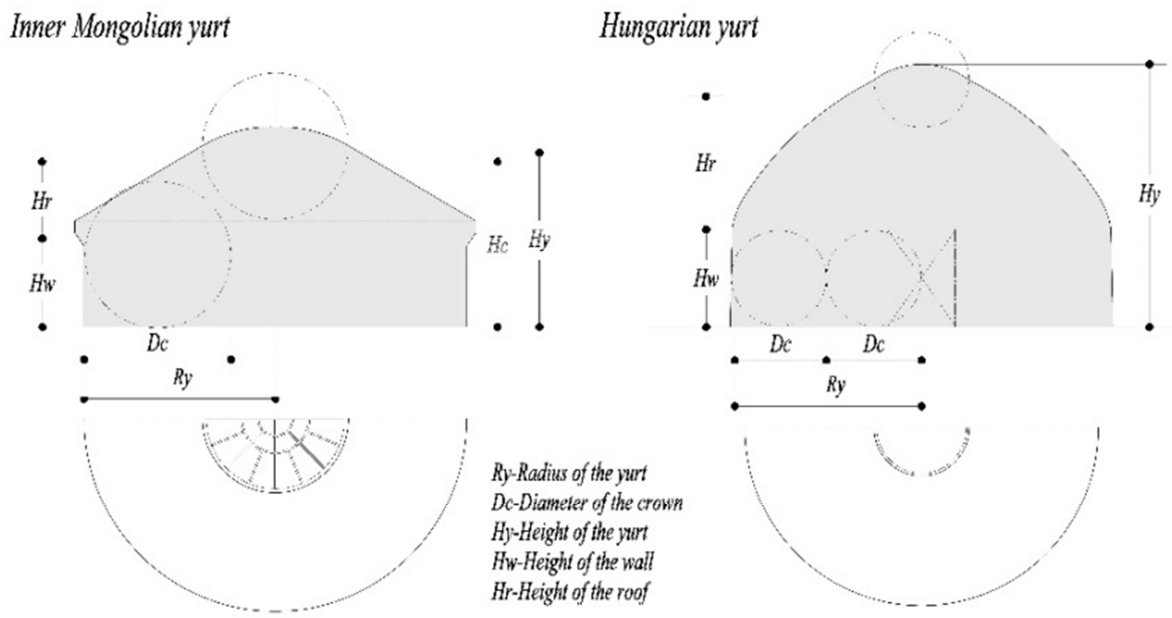

Fig. 5. Drawing of Inner Mongolian and Hungarian yurt

Middle East Yurt: In Kazakhstan, Kyrgyzstan, Turkmenistan, and Uzbekistan some people live the yurt, which is a bit similar than the Mongolian yurt (Fig. O). Crown is similar to the Hunnu yurt's crown, which is the so-called 'Saraalj' crown (Fig. 1). The ends of the poles are curved and the Kazakh yurt has higher roof geometry due to the longer poles. In ancient times they used felt shutter but today, wooden doors are applied 
(Fig. 6). Some yurts in Uzbekistan also have double sided walls, which are significantly taller than other yurts (Fig. 7) and the wall cover is made of woven cloth [17].

Afghanistan Yurt: This yurt type is decisively smaller than the other yurts and the form is taller. Similarly, the crown is also smaller, compared to the other yurts' crowns (Fig. 7) [7]. The old version of the Afghan mobile yurt is made of latticework wooden frame, which is covered with woven reed matting bands in several different colors.

Several long poles are fastened with special knots, supporting the poles to the wooden frame (crown) on the top. There is usually intricately designed felt which is fixed on the top of the roof, while decoration usually appearing inside of the yurt [17].

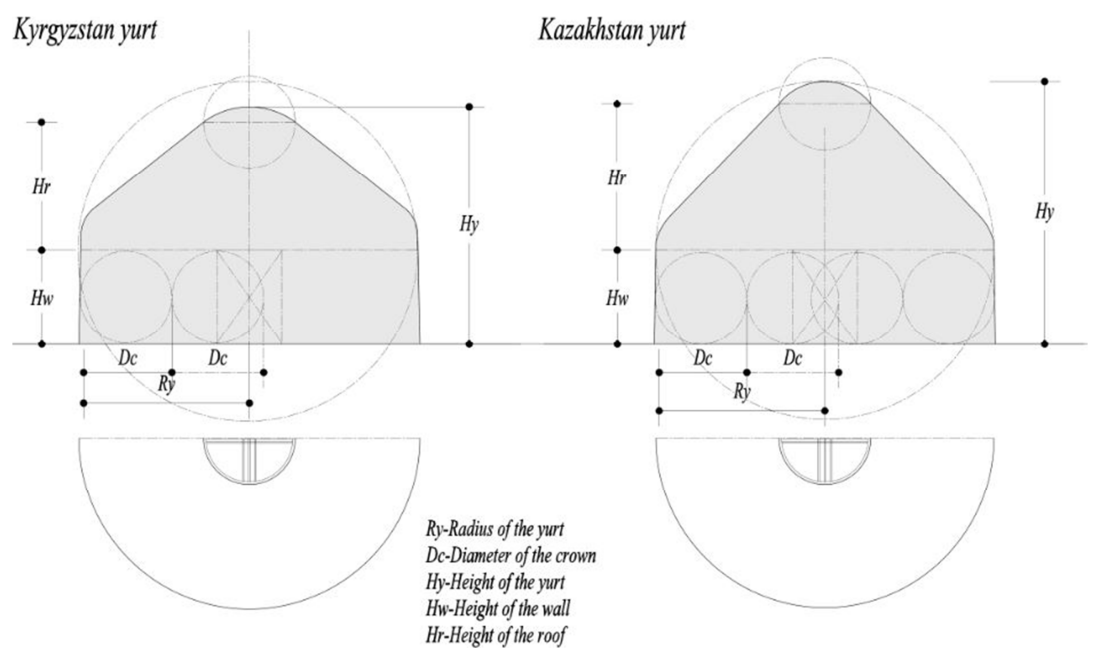

Fig. 6. Drawing of the Kyrgyz and Kazakh yurt

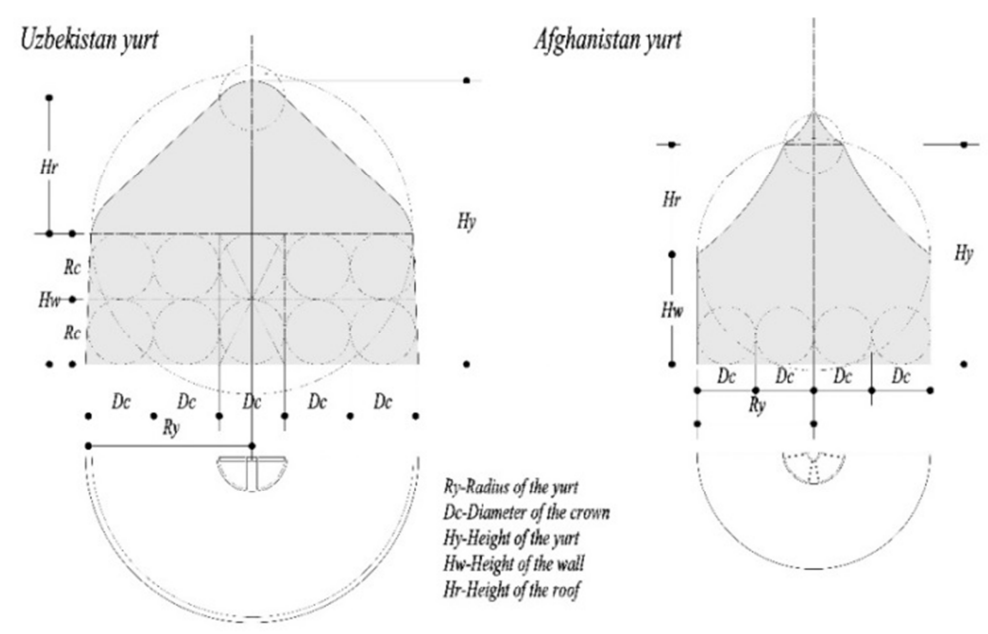

Fig. 7. Drawing Uzbek and Afghanistan yurt 
Iran Yurt: 'Chador' or 'Kapar' are the terms, which mean yurt in Iran. Due to hot and humid weather conditions, this type of yurt is without a crown on top. The walls are usually made by folding lattices, combined with straps. The wall around the yurt is made of multiple vertically standing lattices. To create the roof, they usually use poles or slats, fixed from above into a wooden hoop. In a dome shape, the cylindrical framework of the vertical round wall is attached at the side to the forks of the poles. The wooden hoop is $3-5 \mathrm{~m}$ in diameter, which serves also as a small chimney. The diameter of this kind of yurt is $9-15 \mathrm{~m}$. The rounded wall is covered with several pieces of felt, while the vault covering is managed separately and carpet or felt covers the floor. The door is covered with a curtain or a light wood structure [18], [19].

American Yurt: The American yurt is considered to be the most modern yurt in the world. These yurts are produced using the most advanced materials available. The yurts are mostly being used for tourist in the USA and Canada. These yurts have windows and crowns, which can easily be opened for ventilation. The poles are connected to each other and supported by steel cables. The interior consists of several rooms, which are elevated off the ground. The shape is similar to the Mongolian yurt but the walls and doors are higher (Fig. 8) [20], [21], [2].

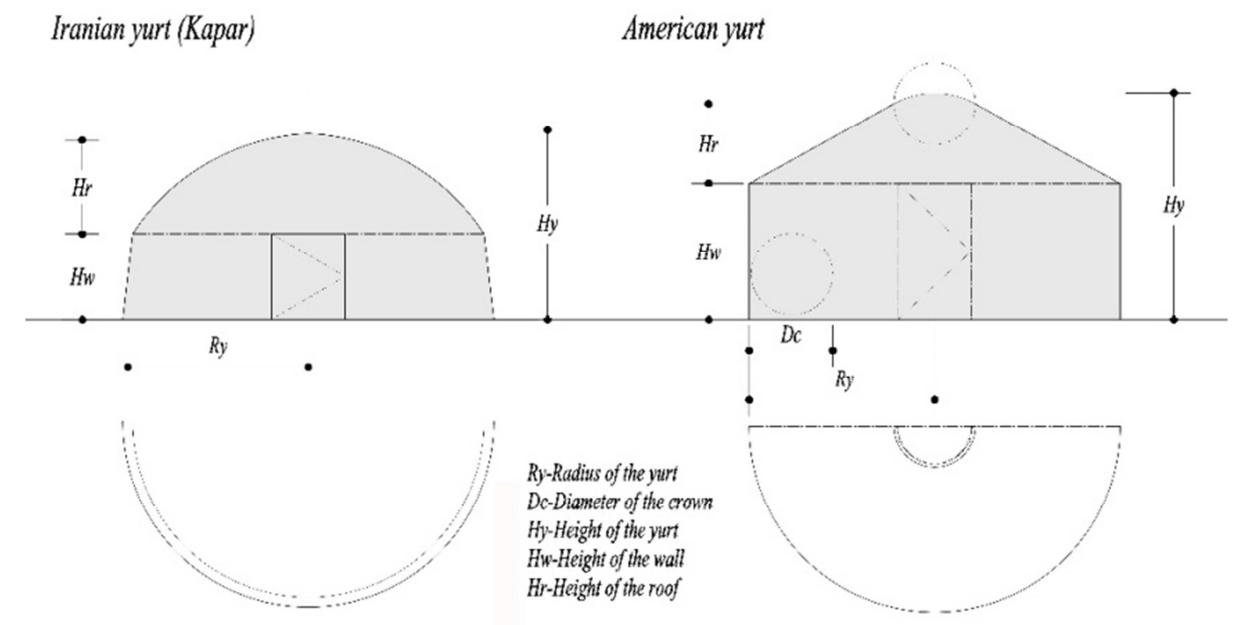

Fig. 8. Drawing of the Iranian and American yurt

In Table I all available yurt types are systemized according to place, historical time of usage, functionality, structure and - in addition - temperature values of the climate zones [22].

Dymaxion 'Wichita' House: In 1940 Buckminster Fuller designed the Dymaxion House, which was considered to be the answer to many housing shortages following the $2^{\text {nd }}$ World War. The shape and form were very similar to the yurt, using recycled metals, including steel, aluminum, and Plexiglas. A single-family unit can weigh as much as $2700 \mathrm{~kg}$. 
Table I

Systemized general information of different yurts with additional climate data

\begin{tabular}{|c|c|c|c|c|c|c|}
\hline 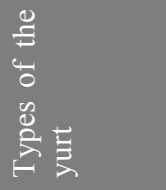 & 吾 & 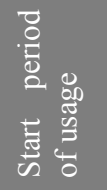 & 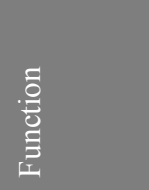 & 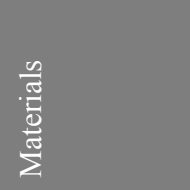 & $\begin{array}{c}5 \\
0 \\
0 \\
0\end{array}$ & 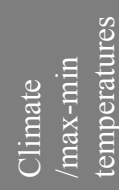 \\
\hline Hunnu yurt & Mongolia & 4th BC & residential & $\begin{array}{l}\text { wooden } \\
\text { frame, felt } \\
\text { cower }\end{array}$ & Saraalj & $\begin{array}{l}30.6- \\
(-22.5)\end{array}$ \\
\hline $\begin{array}{l}\text { Mongolian } \\
\text { empire yurt }\end{array}$ & Mongolia & $\begin{array}{l}13 \text { th } \\
\text { century }\end{array}$ & residential & $\begin{array}{l}\text { wooden } \\
\text { frame, felt } \\
\text { cower }\end{array}$ & $\begin{array}{l}\text { Double } \\
\text { Saraalj }\end{array}$ & $\begin{array}{l}30.6- \\
(-22.5)\end{array}$ \\
\hline $\begin{array}{l}\text { Mongolian } \\
\text { Yurt }\end{array}$ & $\begin{array}{l}\text { Mongolia } \\
\text { Buriad } \\
\text { Khalimik }\end{array}$ & 1900 & $\begin{array}{l}\text { residential } \\
\text { tourism } \\
\text { symbol }\end{array}$ & $\begin{array}{l}\text { wooden } \\
\text { frame, felt } \\
\text { cower, cotton } \\
\text { cover, water } \\
\text { protection }\end{array}$ & $\begin{array}{l}\text { Khorol, } \\
\text { Saraalj, } \\
\text { Sarkhinag } \\
\text { Khorol } \\
\text { with } \\
\text { trussed } \\
\text { wood } \\
\end{array}$ & $\begin{array}{l}30.6- \\
(-22.5)\end{array}$ \\
\hline $\begin{array}{l}\text { Inner } \\
\text { Mongolian } \\
\text { Yurt }\end{array}$ & $\begin{array}{l}\text { Inner } \\
\text { Mongolia }\end{array}$ & 1900 & $\begin{array}{l}\text { residential } \\
\text { tourism }\end{array}$ & $\begin{array}{l}\text { wooden } \\
\text { frame, felt } \\
\text { cower }\end{array}$ & $\begin{array}{l}\text { Khorol } \\
\text { with } \\
\text { trussed } \\
\text { wood }\end{array}$ & $\begin{array}{l}36.4- \\
(-14.3)\end{array}$ \\
\hline $\begin{array}{l}\text { Hungarian } \\
\text { yurt }\end{array}$ & Hungary & $\begin{array}{l}\text { 7th } \\
\text { century }\end{array}$ & $\begin{array}{l}\text { residential } \\
\text { tourism }\end{array}$ & $\begin{array}{l}\text { wooden } \\
\text { frame, felt } \\
\text { cower }\end{array}$ & Saraalj & $\begin{array}{l}34.6- \\
(-12.2)\end{array}$ \\
\hline Kyrgyz yurt & Kyrgyzstan & $\begin{array}{l}13 \text { th } \\
\text { century }\end{array}$ & $\begin{array}{l}\text { residential } \\
\text { tourism } \\
\text { symbol } \\
\end{array}$ & $\begin{array}{l}\text { wooden } \\
\text { frame, felt } \\
\text { cower }\end{array}$ & Saraalj & $\begin{array}{l}37.1- \\
(-11.0)\end{array}$ \\
\hline Kazakh yurt & $\begin{array}{l}\text { Mongolia, } \\
\text { Kazakhstan } \\
\text { Turkmenista } \\
\text { n Uzbekistan } \\
\text { Tajikistan }\end{array}$ & $\begin{array}{l}\text { 13th } \\
\text { century }\end{array}$ & $\begin{array}{l}\text { residential } \\
\text { tourism }\end{array}$ & $\begin{array}{l}\text { wooden } \\
\text { frame, felt } \\
\text { cower }\end{array}$ & Saraalj & $\begin{array}{l}37.1- \\
(-11.0)\end{array}$ \\
\hline $\begin{array}{l}\text { Double wall } \\
\text { yurt }\end{array}$ & $\begin{array}{l}\text { Mongolia } \\
\text { Kazakhstan } \\
\text { Uzbekistan }\end{array}$ & $\begin{array}{l}\text { 13th } \\
\text { century }\end{array}$ & $\begin{array}{l}\text { residential } \\
\text { tourism }\end{array}$ & $\begin{array}{l}\text { wooden } \\
\text { frame, felt } \\
\text { cower }\end{array}$ & Saraalj & $\begin{array}{l}37.1- \\
(-11.0)\end{array}$ \\
\hline Afghan yurt & Afghanistan & $\begin{array}{l}13 \text { th } \\
\text { century }\end{array}$ & $\begin{array}{l}\text { residential } \\
\text { tourism }\end{array}$ & $\begin{array}{l}\text { wooden } \\
\text { frame, felt } \\
\text { cower }\end{array}$ & Saraalj & $\begin{array}{l}37.1- \\
(-11.0)\end{array}$ \\
\hline Iran yurt & Iran & $\begin{array}{l}13 \text { th } \\
\text { century }\end{array}$ & $\begin{array}{l}\text { residential } \\
\text { tourism }\end{array}$ & $\begin{array}{l}\text { wooden } \\
\text { frame, felt } \\
\text { cower }\end{array}$ & - & $\begin{array}{l}43.9- \\
4.9\end{array}$ \\
\hline $\begin{array}{l}\text { American } \\
\text { yurt }\end{array}$ & $\begin{array}{l}\text { USA, } \\
\text { Canada }\end{array}$ & 1967 & $\begin{array}{l}\text { residential } \\
\text { tourism }\end{array}$ & $\begin{array}{l}\text { wooden frame, } \\
\text { felt cower, } \\
\text { midbrain water } \\
\text { protection }\end{array}$ & $\begin{array}{l}\text { American } \\
\text { yurt crown }\end{array}$ & $\begin{array}{l}44.9- \\
(-11.0)\end{array}$ \\
\hline
\end{tabular}

Pollack Periodica 13, 2018, 3 
Both the yurts and Dymaxion House are provided with the system of natural ventilation: the dome of the Dymaxion House induces a 'dome chilling effect' [5], [6]. At the center of the interior, there is a hole that functions both as heating (chimney) and for natural lighting (skylight). The 'Wichita house' has some windows on the wall and had a rotating vent at the top, fitted with the rudder. The final design of the house used a central vertical stainless steel strut on a single foundation. The structures look similar to that of an umbrella.

Fuller studied the effects of wind drag on the house. In his wind tunnel analysis, the house was exposed to wind speed from 12-miles an hour $(19.3 \mathrm{~km} / \mathrm{h})$ to 70 -miles an hour $(112.6 \mathrm{~km} / \mathrm{h})$, from which point the flat planking began to fly off in parallel with the wind direction [5], [23] (Fig. 9). Rudders that rotated with the wind was the new design innovation implemented by Fuller. The induced vertical-driven vortex sucks cooler air downward if properly ventilated [5], [6]. A tornado once passed 270 meters from the 'Wichita house' in 1964, and was not able to cause considerable damage to the structure. The Dymaxion House house never went into mass-production but Fuller's experiment with the wind was a remarkable success [6].

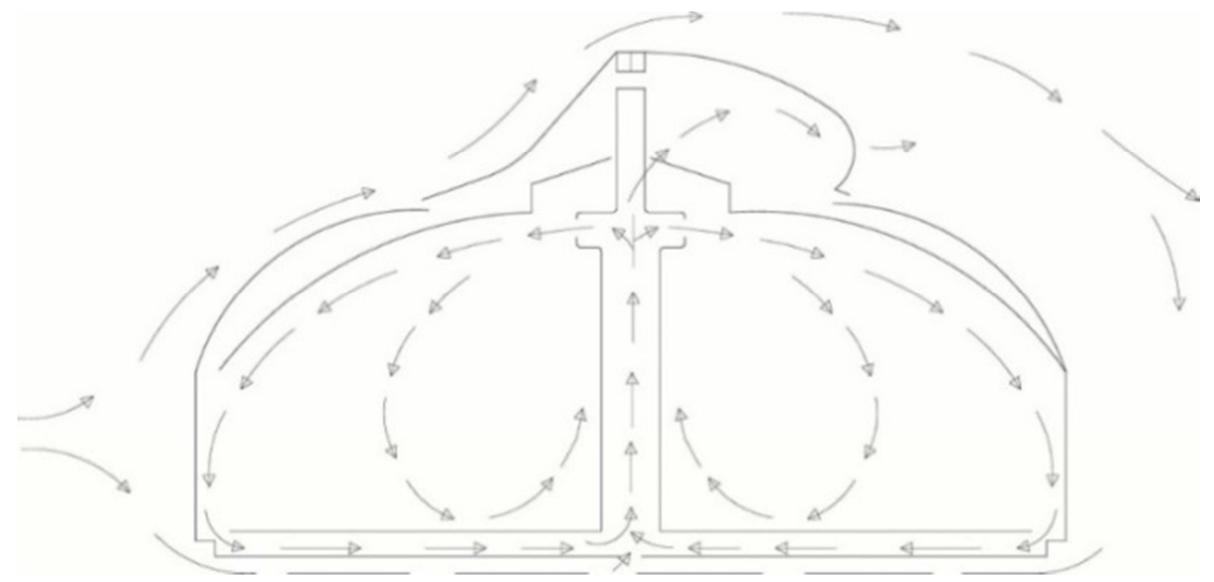

Fig. 9. Dymaxion Deployment unit (Wichita house) [7]

\section{Conclusion}

The yurt is one of the most typical nomadic traditional vernacular architecture solutions. Some countries are losing the nomadic culture and yurt house because the lifestyle is changing to the urban form of life. In Mongolia, people use the yurt in the city called 'Ger area', - a settlement zone that does not connect to any water supply and wastewater treatment system or heating supply system. On the basis of comprehensive literature and scientific paper research, a review is provided about architectural, structural, and material systematization of the yurt, creating a complete yurt-typology. Regarding the professional and scientific publications, it is apparent that practically no research is existing about the building physics performance of the yurt. Since 
researchers usually write about Mongolian, Kazakh, and Kyrgyz yurt's architectural and structural characteristics, without considering any climate and/or energy issues, in following research steps we see the necessity of analysis of the physical performance of buildings, with special regard to efficiency and environmentally conscious and comfortable design. Calculation results can help to develop contemporary sustainable, light weight-transportable housing solutions.

\section{Reference}

[1] Daajav B. Yurt as the origin of Mongolian architecture, (in Mongolian) Ulaanbaatar, Mongolia, Translated, 2006.

[2] King P. The complete Yurt handbook. Eco-logic books, 2001.

[3] Kemery B. Yurt: Living in the round, Gibbs Smith, Publisher, Utah, USA, 2006.

[4] Bayarsaikhan B. Put up a Ger, Ulaanbaatar, Mongolia, 2006.

[5] Mrkonjic K. Autonomous lightweight houses: Learning from yurts, The $23^{\text {rd }}$ Conference on Passive and Low Energy Architecture, Geneva, Switzerland, 6-8 September 2006, p. 4.

[6] Gorman M. J. Buckminster fuller: Designing for mobility, Italy, 2005.

[7] Bat-Ulzii B., Dagmid O. Encyclopedia of the ger, the dwelling house of Mongols, (in Mongolian) 2nd ed, Ulaanbaatar, Mongolia, Translated, 2016.

[8] Gao X., Zeing H. K., Jin G. Green design property of Mongolian yurt, (in Chinese) Inner Mongolia Agricultural University, China, Translated, 2009

[9] Guan X. W., Di L. An investigation on the techniques and skills of making Mongolia yurts in the Zhenglan-qi Mongolia yurts factory, (in Chinese) Journal of Guangxi University for Nationalities (Natural Science Edition), China, Vol. 4, Translated, 2006, pp. 49-52.

[10] Altangerel M., Dashdendev N. B., Bikales E. G., Sabloff L. W. Modern Mongolia, Reclaiming Genghis Khan, USA, 2001.

[11] Salvalai G., Imperadori M., Lumina F., Mutti E., Polese I. Architecture for refugees, resilience shelter project: A case study using recycled skis, Procedia Engineering, Vol. 180, 2017, pp. 1110-1120.

[12] Chong, G. C.. A study on spatial composition and elements of Ger architecture in Mongolia, Journal of the Korean Institute of Rural Architecture, Vol. 16, No. 1, 2014, pp. 111-117.

[13] Nikiforov B. S., Baldorzhieva V. B., Nikiforov S. O., Markhadaev B. E. The design of Mongolian yurts (Ger): Genesis, typology, frame and modular technologies and their transformation, Sciences of Europe, Vol. 11, No. 1, 2017, pp. 56-69.

[14] Liu H. Y., Li Z. M., Ko F. K. A fractional model for heat transfer in Mongolian yurt, Thermal Science, Vol. 21, No. 4, 2017, pp. 1861-1866.

[15] Zhang X. H., Bai Y. T. Study on Mongolian yurt features and its environmentally friendly design, Joint International Conference on Materials Science and Engineering Application and International Conference on Mechanics, Civil Engineering and Building Materials, Nanjing, China, 21-23 April 2017, p. 6.

[16] Nemcsics Á. Contribution to a round church reconstructed from its foundation wall, Pollack Periodica, Vol. 6, No. 1, 2011, pp. 87-98.

[17] Dupree L. Afghanistan, Princeton University Press, 1980.

[18] Kuzmina E. E. The origin of the Indo-Iranians, Leiden, Boston, USA, 2007.

[19] Javad E., Namdar S. A. Sustainable systems in Iranian traditional architecture, Procedia Engineering, Vol. 21, 2011, pp. 553-559. 
[20] Apak K. Modernization of the 'Yurt' tensile structure, International Conference on Adaptable Building Structures, Eindhoven, The Netherlands, 3-5 July 2006, Paper 10-295.

[21] U.S. Patent No. 15/295,654, Housing system, Barry R. M. 2015.

[22] Liedl P., Hausladen G., Saldanha M. Building to suit the climate: A Handbook, Walter de Gruyter, 2012.

[23] Haber I., Farkas I. Analysis of air-flow at photovoltaic modules for cooling purposes, Pollack Periodica, Vol. 7, No. 1, 2012, pp. 113-121. 